\title{
The quality of lives of unaccompanied minors migrating to Europe
}

\author{
M. Jackulikova (Maria Jackulikova) ${ }^{1,2}$, E. Vrankova (Emilia Vrankova)2, M. Bartkovjak

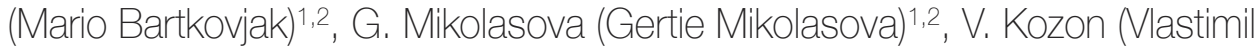 \\ Kozon) $)^{1,3}$, M. Olah (Michal Olah)2, M. Mikloskova (Monika Mikloskova)2
}

${ }^{1}$ Refugee Medical Care, Lesbos camp, Greece.

${ }^{2}$ John Paul II School of Missiology, Bratislava, Slovakia.

${ }^{3}$ General Hospital (AKH), Vienna Austria.

\section{E-mail address:}

maria.jackulikova@gmail.com

\section{Reprint address:}

Maria Jackulikova

NPHO Support Mission Lesbos Greece and John Paul II School of Missiology

Bratislava

Slovakia

Source: Clinical Social Work and Health Intervention

Pages: $28-31$

Volume: 11

Issue: 1

\section{Reviewers:}

Mageswari Rajoo, P/hD SAAaRMM Kualal Lumpur, Malaysia

Jirina Kafkova, MSF, Freetown, Sierra Leone

\section{Key words:}

Asylum Procedure. Legal Protection of Children. Living Conditions. Migration. Refugee Camp. Social Suffering. Unaccompanied Minors.

\section{Publisher:}

International Society of Applied Preventive Medicine i-gap

CSWHI 2020; 11(1): 28 -31; DOI: 10.22359/cswhi_11_1_04 (C) Clinical Social Work and Health Intervention

\section{Abstract:}

Migration of minors has a lot in common with the migration of adults as well as a few features related to the vulnerability of the underage. The principal subject of the thesis is a comparison of official statistical documents concerning the asylum system and the quality of lives of unaccompanied minors in the process of their admission into Greece and Italy which are at the forefront of the migrant influx.The period analysed is the year 2018. Based on the principles of the UN Charter, international organizations deal with the minors' needs and emphasize the universality of children's rights. The analysis of the children's protection services available in both countries uncovers inefficiencies of the systems currently in place. 


\section{Introduction}

The number of arrivals of unaccompanied underage migrants continues to rise. This phenomenon is becoming increasingly complex due to the high number of underage migrants looking for asylum in Greece and Italy, which are the two countries that are affected by migration the most. Just like adults, children face horrible roads and experiences, which occur during the three stages of the escape. The initial stage is in the country of their origin, followed by their passage to safety, with the final stage being the arrival and reception in the host country. The conditions under which they are received are unfortunately very humiliating and inhuman. The migration of minors has a lot in common with the migration of adults as well as a few additional characteristics which are related to the vulnerability of minors.1-8

\section{Methods}

The principal subject of the thesis is a comparison of official statistical documents concerning the asylum system and the quality of lives of unaccompanied minors in the process of their admission into Greece and Italy which are at the forefront of the migrant influx. The period analysed is the year 2018. The work is complemented by studies which are illustrated on cases from a similar period.

\section{Results and Discussion}

The quality standard or in this case, the poor quality standard of life the unaccompanied minors experience is due to sudden disruption of their everday lives as well as the influence of pathological conditions in the reception centres of both countries. The unaccompanied underage migrants have damaged health affected by psychosocial as well as social suffering.

The decisive factors for the health of migrants are largely determined by the availability, accessibility, acceptability and quality of services in the host country.

Based on the principles of the UN Charter, international organizations deal with the minors' needs and emphasize the universality of children's rights. However, the reality at the reception facilities of the host countries is different. Therefore, a change of how host contries deal with migrants must be iniciated by the UNHCR and EU.

The influence of the EU on health / social care of migrants can be analyzed with regard of the health issues associated with the countries of origin of the migrants living at reception centers in Italy and Greece. Social suffering of children is comparable, in many cases, to the suffering of adults.

The comparative analysis rendres information regarding the situation of unaccompanied minors during 2018. In our research we highlight the way the asylum system works, how it causes the social exclusion of children, and how this social exclusion can transform to serious mental as well as physical problems.

The analysis of the children's protection services available in both countries uncovers inefficiencies of the systems currently in place. For in-

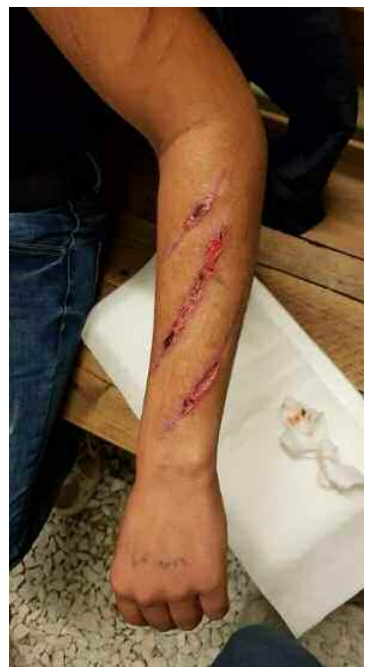

Self-harm

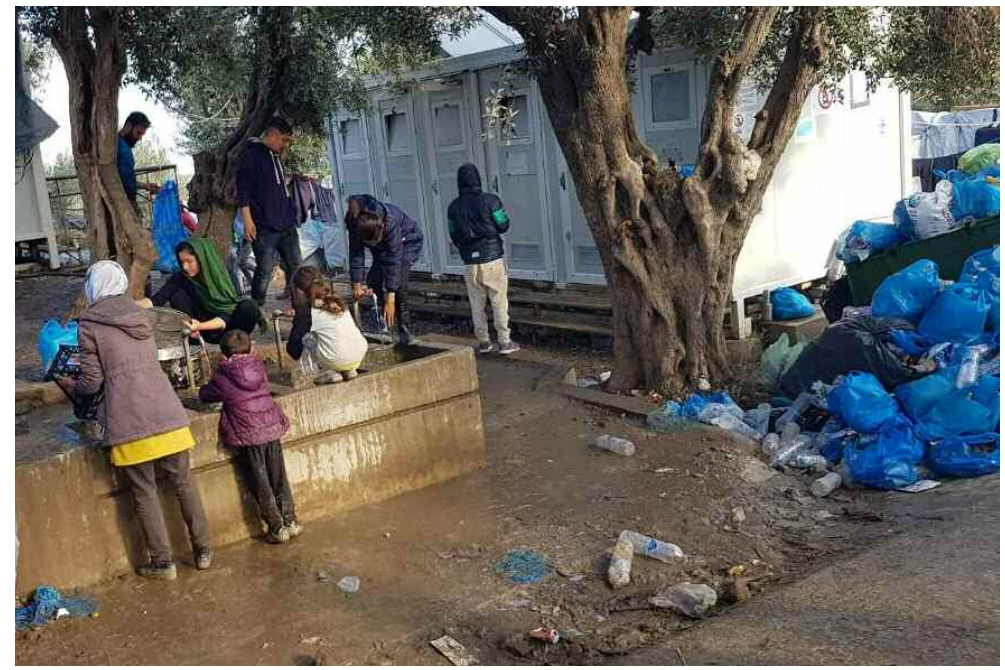

Living conditions in Moria camp 
stance children do not have access to protection and safety.

Children also have to face separation from their families, detention, limited access to education and leisure activities. Other problems they often encounter include human trafficking and safety issues.

Nowadays, more than half of the refugee children in Greece are on the waiting list for accomodation due to the insufficient capacity of the shelters. Many of the children remain in closed reception facilities or police cells, accomodated alongside adults or even in the aisles of the facilties. In order to deal with the unfavourable life situation they often take drugs, drink alcohol, try to selfharm or even commit demonstrative suicides.

Under international, European, Greek as well as Italian law, it is defined that an unaccompanied minor is a minor who is a third-country citizen and has the same protection as a minor of European nationality.

In fact, children in refugee camps are affected by social inequalities, instability and they are exposed to high amounts of stress caused by the migration process which in turn is affecting their physical, mental and psychological health.

One of the major differences between the migrant arrivals to Greece and Italy are the nationalties of the migrants. Syrians and Iraqi Afghans, are present almost exclusively in Greece but are absent in Italy. Nationals from Nigeria, Senegal, Ukraine, Mali, Gambia are represented in Italy but are missing in Greece. Pakistanis are present in large numbers in both Greece and Italy however, it is important to stress that the presence of Pakistanis was far from standard.

During 2018, the asylum service received 2,639 applications from unaccompanied children, where the prevalence of applications received were from young boys ( 2455 ) compared to the number of applications from girls (194). The asylum process at the end of 2018 was carried out in 23 places in Greece. Asylum applications for unaccompanied minors in Italy amounted to 3,676 children in 2018.

Overall, in Greece the asylum service registered 66969 asylum applications, accounting for $11 \%$ of the total number of applications submitted in the EU, making Greece the third largest Member State after Germany (28\%) and France (19\%).

In 2018, Syrians were repeatedly the largest group of asylum seekers with 13390 asylum applications, 4834 applications from Turkish nationals were also received.

Italy received 7368 asylum applications for 2018 of which 818 were citizens of Eritrea and 838 asylum seekers from Iraq. 1589 asylum applications were received from Pakistan.

Tab. 1 Arrivals to Europe in 2018, broken down by country of origin: Greece and Italy

\begin{tabular}{|l|c|l|c|}
\hline \multicolumn{2}{|c|}{ Greece } & \multicolumn{2}{c|}{ Italy } \\
\hline Syria & 13390 & Pakistan & 7368 \\
\hline Afghanistan & 11926 & Nigeria & 6336 \\
\hline Iraq & 9731 & Bangladesh & 5026 \\
\hline Pakistan & 7743 & Senegal & 2867 \\
\hline Turkey & 4834 & Ukraine & 2517 \\
\hline Albania & 3319 & Mali & 2266 \\
\hline Iran & 1763 & Gambia & 2101 \\
\hline Bangladesh & 1552 & El Salvador & 1735 \\
\hline Palestine & 1519 & Morocco & 1734 \\
\hline Georgia & 1460 & Ivory Coast & 1668 \\
\hline & & Guinea & 1421 \\
\hline & & Ghana & 1171 \\
\hline & & Georgia & 1086 \\
\hline
\end{tabular}




\section{Conclusion}

Based on the principles of the UN Charter, international organizations deal with the minors' needs and emphasize the universality of children's rights. However, the reality at the reception facilities of the host countries is different. Therefore, a change of how host contries deal with migrants must be iniciated by the UNHCR and EU.

\section{References:}

1. AIDA. (2019). Report 2018. WFP Rome. 2019, 105 p.

2. BLITZ, K B et al, (2017) Health Challanges in Refugee Reception. DATELINE EUROPE 2016, International Journal of Environmental Research and Public Health..14. 1484. 10.3390/ijerph14121484.

3. HAJ ALI P, PUTEKOVA S, KABATOVA J, MARTIKOVA J, ZOLLEROVA K, BUCKO L, RADKOVA L, VLCEK R, GREY E, OLAH M, DURICOVA Z, SVITEK R, SIMONEK T, OTRUBOVA J, BIBZA M, KOLIBAB M, MAMOVA A, PALENIKOVA M, MURGOVA A, TKACOVA L, KALATOVA D, JANKECHOVA M, BYDZOVSKY J, KHALIL I, MICHALIKOVA L, MRAZOVA M, LISKOVA A, HERDICS G, CARNECKY M, KHALED I (2016) Are Migrants From Middle East Carriers of resistant bacteria. Clin. Soc. Work Health Intervention 7. 2016. 3. 9-14.
4. HARDY M, BARTKOVJAK M, BERESOVA A, KNOSKOVA E, RADKOVA L, OTRUBOVA J, RABAROVA L, TOPOLSKA A, POLONOVA J, KALATOVA D, MIKOLASOVA G, PROCHAZKOVA K., STANKOVA P, MRAZOVA M, VALACH M, OLAH M, JACKULIKOVA M, DRGOVA J, PALENIKOVA M, BARKASI D, OTRUBOVA J, HOFBAUEROVA B, SCHIFFERDECKEROVA M, HATAPKOVA Z, KOVAC R (2019) Is the homeless shelter population a public Health Threat? Lek Obz (Med Horizon) 68, 2019, 4, 151-152.

5. KOVAC R, MIKLOSKOVA M (2013) The impact of early childhood to the risk of homelessness. Int.J. Prenat Perinat Psychol Med., 25. 2013, S1,42.

6. TOMANEK P, HARDY M, POLONOVA J, MIKLOSKOVA M, MIKOLASOVA G, BUCKO L, MRAZOVA M, KARVAJ M, JOBOVA M, VALLOVA J, HULKOVA V, BOZIK J, SLOVAK J, VLCEK R, BENCA J, SKOPOVA M, JANKECHOVA M, SHAHUM A (2017) St Louise Hospital for Marginalized and Homeless population. Clin. Soc. Work Health Intervention, 8, 2017, 1.13.

7. UNITED NATIONS COMMISION FOR REFUGEES. ( 2019) .Greece: Fact Sheet June 2019, July 2019.

8. UNITED NATIONS COMMISION FOR REFUGEES. ( 2019). Annual Report 2018. UN Genève, 2019, 355p. 